\title{
ANALISIS PERBANDINGAN ALGORITMA DJIKSTRA, A-STAR, DAN FLOYD WARSHALL DALAM PENCARIAN RUTE TERDEKAT PADA OBJEK WISATA KABUPATEN DOMPU
}

\author{
Rusydi Umar ${ }^{1}$, Anton Yudhana ${ }^{2}$, Andi Prayudi*3 \\ ${ }^{13}$ Teknik Informatika, Universitas Ahmad Dahlan \\ ${ }^{2}$ Teknik Elektro, Universitas Ahmad Dahlan \\ e-mail : ${ }^{1}$ rusydi@mti.uad.ac.id, ${ }^{2}$ eyudhana@ee.uad.ac.id, ${ }^{3}$ andi1807048016@webmail.uad.ac.id, \\ *Penulis Korespondensi
}

(Naskah masuk: 11 Desember 2019, diterima untuk diterbitkan: 18 Maret 2021)

\begin{abstract}
Abstrak
Diera industri 4.0, penggunaan peta tidak lagi berbentuk lembaran ataupun buku. Kini terdapat sebuah layananan peta digital yaitu platform Leafleat.js, yang memudahkan penggunanya untuk mendapatkan informasi rute dari objek ke objek lainnya dan mencari lokasi hampir diseluruh dunia. Pada penelitian ini menggunakan objek yang real yaitu menampilkan lokasi sebenarnya menggunakan platform Leaflet.js dan parameter yang berbeda, dari hal tersebut penelitian ini akan membandingkan kinerja dari Algoritma Dijkstra, A* dan Floyd Warshall untuk menentukan waktu proses pencarian rute terdekat dari objek wisata ke objek wisata lain menggunakan bahasa pemograman PHP. Hasil pengujian program didapatkan jarak dan rute yang sama serta rata-rata waktu proses program yang berbeda. Waktu proses algoritma Dijkstra sebesar 0,0060 detik, algoritma A* sebesar 0,0067 dan algoritma Floyd Warshall sebesar 0,0433 detik. Berdasarkan hasil tersebut bahwa algoritma Dijkstra lebih unggul dalam proses pencarian rute.
\end{abstract}

Kata kunci: Algoritma, Djikstra, A-Star, Floyd Warshall

\section{COMPARATIVE ANALYSIS OF DJIKSTRA, A-STAR, AND FLOYD WARSHALL ALGORITHM IN SEARCHING THE NEAREST ROUTE SEARCH TO TOURISM OBJECT IN DOMPU REGENCY}

\begin{abstract}
In the industrial era 4.0, the use of maps is no longer made of book sheets. Now a digital map service is available, the Leafleat.js platform, which provides users to get route information from other attractions and find locations that have been saved by the world. In this study using real objects that display the actual location using the Leaflet.js platform and different parameters, from this study will compare the performance of the Dijkstra, $A$ * and Floyd Warshall Algorithms for the process of finding other tourist information using the PHP programming language. The results of testing the program obtained the same distance and route with different program processing time. Dijkstra algorithm processing time is 0.0060 seconds, $A^{*}$ algorithm is 0.0067 and Floyd Warshall algorithm is 0.0433 seconds. Based on these results, Dijkstra is superior in the route search process.
\end{abstract}

Keyword: Algorithms, Djikstra, A-Star, Floyd Warshall

\section{PENDAHULUAN}

Diera industri 4.0, penggunaan peta tidak lagi berbentuk lembaran ataupun buku. Kini terdapat sebuah layananan peta digital yaitu platform Leafleat.js, yang memudahkan penggunanya untuk mendapatkan informasi rute dari objek ke objek lainnya dan mencari lokasi hampir diseluruh dunia. Leaflet.js merupakan library javascript open source yang berguna untuk membangun aplikasi peta interaktif berbasis web (Manurung, 2018). Terdapat banyak Algortima yang menyelesaikan permasalahan pencarian rute terdekat diantaranya adalah algoritma A* (A Star), Floyd Warshall, Dijkstra, dan Bellmanford. Banyaknya penelitian yang telah melakukan hal yang serupa, diantaranya penggunaan algoritma yang sama untuk mencari rute terdekat dari objek wisata ke objek wisata lainnya dan penerapan ke sebuah game.

Terdapat beberapa penelitian sebelumnya yang menjadi dasar dari penelitian ini salah satunya adalah yang dilakukan oleh (Suyitno, 2016) menggunakan algoritma $A^{*}$ untuk mencari rute terdekat dari rumah menuju objek wisata Candi Jiwa Batujaya yang 
ditampilkan melalui platform Google Maps. berikutnya dilakukan oleh (Pugas, Somantri \& Satoto, 2014) membandingkan algoritma $A^{*}$ dengan Dijkstra untuk mencari rute terdekat antara objek wisata ke objek wisata lain di Kota Sawahlunto yang ditampilkan melalui platform Mapserver dengan parameter jarak tempuh antara objek wisata. Penelitian selanjutnya dilakukan oleh (M. Azan Cahyadi, Bambang, Widhiarso \& Yohannes, 2016) membandingkan algoritma Dijkstra, A*, dan Floyd Warshall untuk menentukan jalur terpendek pada Bacteria Defense Game dengan parameter Weight, Path Count, dan Checked Node. dan terakhir dilakukan oleh (Sazaki, Satria, Primanita \& Syahroyni., 2018) membandingkan algoritma $A^{*}$ dan Dinamic Pathfinding dalam pencarian rute terpendek yang ada pada Simulation Game khususnya Car Racing Game.

Pada penelitian ini terdapat perbedaan dengan penelitian sebelumnya yakni, menggunakan objek yang real yaitu menampilkan lokasi sebenarnya menggunakan platform Leaflet.js dan parameter yang berbeda. Dengan dasar tersebut kami akan membandingkan kinerja dari Algoritma Dijkstra, A* dan Floyd Warshall untuk menentukan waktu proses pencarian rute terdekat dari objek wisata ke objek wisata lain menggunakan Bahasa pemograman PHP. PHP yaitu skrip bahasa pemograman yang membuat dokumen HTML secara langsung eksekusi oleh web server.(Sidik, 2017).

Algoritma Dijkstra adalah algoritma greedy (serakah) yang digunakan untuk menyelesaikan masalah dalam jalur terpendek menggunakan grafik berarah dengan bobot tepi dihargai non-negatif (Agusta \& Ferdinand, 2017). Algoritma A* merupakan bentuk pencarian terbaik yang paling populer, Algoritma ini digunakan untuk menemukan jalur dari node awal yang diberikan ke node tujuan. Algoritma ini memperkiraan nilai heuristik $\mathrm{h}(\mathrm{x})$ yang memberikan perkiraan rute terbaik yang akan dilewati oleh simpul. (Shabina Banu Mansuri, 2018). Algoritma Floyd-Warshall adalah metode yang memberikan solusi dengan melihat jawaban yang akan diperoleh sebagai keputusan yang saling terkait. Ini berarti bahwa solusi terbentuk dari solusi yang berasal dari tahap sebelumnya, dan ada kemungkinan lebih dari satu solusi. Algoritma ini ditemukan oleh Warshall. (Ningrum \& Andrasto ,2016).

\section{METODE PENELITIAN}

\subsection{Pengumpulan Data}

Pada penelitian ini data objek wisata didapatkan secara langsung pada Dinas Kebudayaan dan Pariwisata (DISBUDPAR) Kabupaten Dompu dan menggunakan platform Google Maps untuk mengambil titik koodinat lokasi objek wisata. Google Maps adalah sebuah aplikasi peta yang diciptakan oleh perusahaan Google yang dapat berjalan didalam browser (Ariyanti, Khairil \& Kanedi, 2015). Google Maps memiliki beberapa fasilitas yang dapat digunakan, yakni menemukan sebuah lokasi dengan memasukkan kata kunci, seperti kota, jalan, nama tempat. (Umar and Hari Prabowo, 2016). Titik koordinat digunakan sebagai dasar penentuan rute terdekat. beberapa objek wisata alam beserta koorditannya dapat dilihat pada table 1 .

Tabel 1. Koordinat Objek Wisata

\begin{tabular}{lllll} 
& & \multicolumn{2}{c}{ Tabel 1. Koordinat Objek Wisata } \\
\hline \multirow{2}{*}{ No } & \multirow{2}{*}{ Kode } & Nama Objek & \multicolumn{2}{c}{ Kooditat } \\
\cline { 3 - 4 } & & & \multicolumn{1}{c}{ Latitude } & Longitude \\
\hline 1 & PLK & Pantai Lakey & -8.7958347 & 118.3798741 \\
2 & PFJ & Pantai Felo & -8.680857 & 118.430676 \\
& & Janga & & \\
3 & PWJ & Pantai Wadu jao & -8.6661146 & 118.4247945 \\
4 & PMT & Puncak Matiti & -8.8636108 & 118.431523 \\
\hline
\end{tabular}

Koordinat pada table 1 didapatkan dari platform Google Maps, dari koodinat tersebut peneliti memasukan ke dalam aplikasi. Marker dipasang setiap titik koodinat objek wisata alam, dapat dilihat pada gambar 1 .

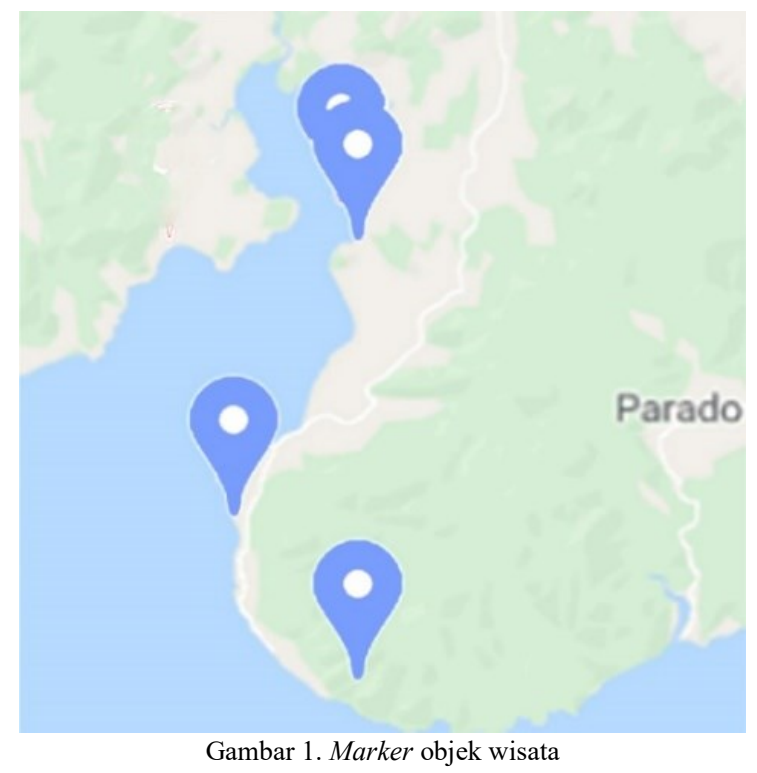

Gambar 2 merupakan tampilan maps menggunakan platform Leafleat.js dan terlihat 4 (empat) buah marker yakni titik koordinat objek wisata.

Gambar 2 merupakan rute perjalanan detinasi wisata. Jarak antara titik diambil menggunakan fitur rute pada platform Google Maps. Dari gambar 2 dapat dilihat bahwa jarak untuk G1 ke E1 adalah 8,7 Km. begitu juga dengan jarak yang lain. 


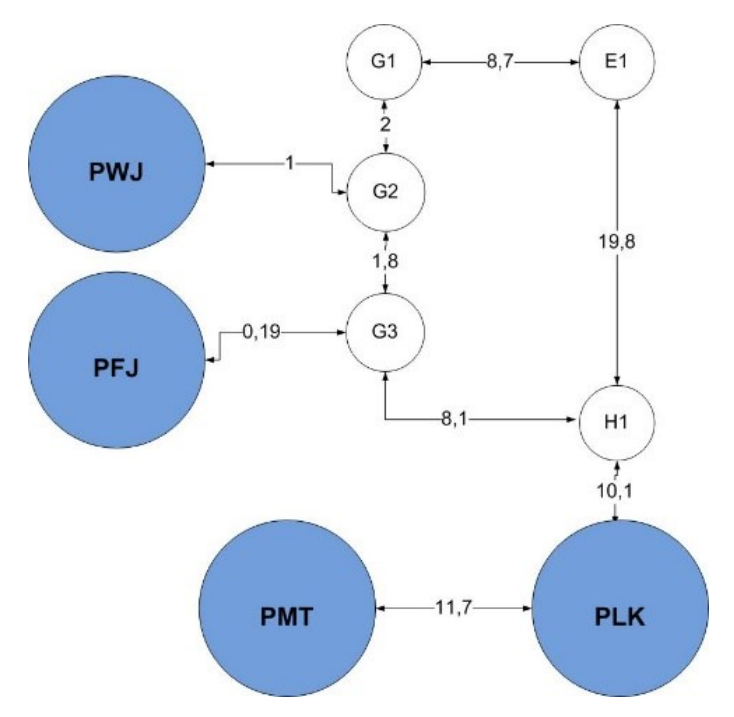

Gambar 2. Rute perjalanan objek wisata

Ketenrangan Simbol :

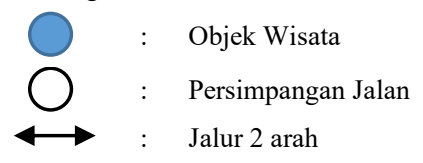

\subsection{Algoritma}

\subsubsection{Algoritma Dijkstra}

Algoritma Dijkstra adalah algoritma greedy (serakah) yang digunakan untuk menyelesaikan masalah dalam jalur terpendek menggunakan grafik berarah dengan bobot tepi dihargai non-negatif (Agusta \& Ferdinand, 2017). Algoritma Dijkstra merupakan algoritma untuk mencari panjang rute terpendek dari sebuah titik $\mathrm{s}$ ke sebuah titik t di graf bobot $\mathrm{G}$, dengan bobot setiap sisi $\mathrm{G}$ adalah bilangan positif (Ardyan, Mulyono \& Suyitno, 2017). Algoritma Dijkstra merupakan algoritma pencari rute terbaik. Prinsip greedy (serakah) digunakan dalam algoritma ini. Bahwa setiap jalur akan dipilih sisi yang berbobot kecil (Wahyuningsih \& Syahreza, 2018). Algoritma Dijkstra bekerja dengan membuat jalur ke satu simpul optimal pada setiap langkah. Jadi pada langkah ke $\mathrm{n}$, setidaknya ada $\mathrm{n}$ node yang sudah diketahui jalur terpendek (Sunardi, Yudhana and Kadim, 2019). Berikut pseudocode algoritma Djikstra.

\subsubsection{Algoritma $A^{*}$}

Algoritma $A^{*} \mathrm{r}$ merupakan bentuk pencarian terbaik yang paling populer, Algoritma ini digunakan untuk menemukan jalur dari node awal yang diberikan ke node tujuan. Algoritma ini memperkiraan nilai heuristik $\mathrm{h}(\mathrm{x})$ yang memberikan perkiraan rute terbaik yang akan dilewati oleh simpul. (Shabina Banu Mansuri, 2018). Algoritma A * adalah algoritma pencarian heuristik, yang menggunakan fungsi heuristik untuk menilai biaya transit node ke node tujuan.(Wang, Wang, Qin, Wu, Duan, Cao \& $\mathrm{Ou}, 2015)$. Algoritma dapat dinyatakan sebagai berikut

$$
f(n)=g(n)+h(n)
$$

Dimana:

$$
\begin{array}{ll}
f(n)= & \text { Hasil perhitungan jarak } \\
g(n)= & \text { Jarak sesungguhnya dari titik awal ke } \\
& \text { titik } \mathrm{n} \\
h(n)= & \text { Jarak heuristic dari titik awal ke titik } \mathrm{n}
\end{array}
$$

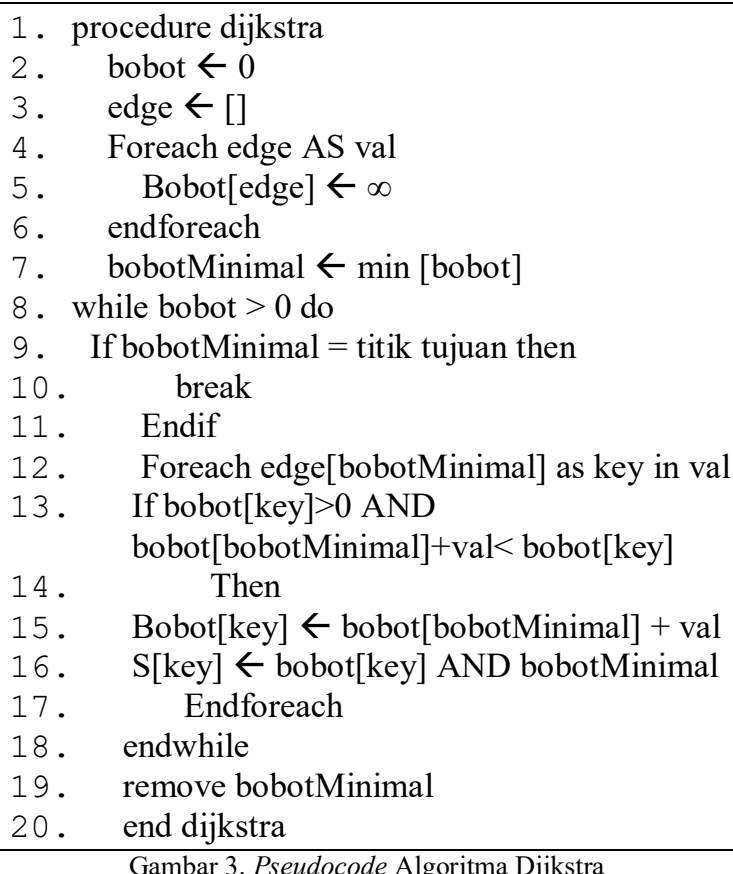

Untuk menghitung jarak heuristic menggunakan metode Euclidean distance pada persamaan (2). Euclidean distance adalah perhitungan jarak dari 2 buah titik dalam Euclidean space. Euclidean space diperkenalkan oleh Euclid, seorang matematikawan dari Yunani sekitar tahun 300 B.C.E. untuk mempelajari hubungan antara sudut dan jarak. Euclidean ini berkaitan dengan Teorema Phytagoras dan biasanya diterapkan pada 1, 2 dan 3 dimensi (Setiawan, Andriyanto, Putro, Pradana, Permana, 2018). Berikut formula Euclidean.

$$
d=\sqrt{\left(x_{1}-x_{2}\right)+\left(y_{1}-y_{2}\right)^{2}}
$$

Sehingga dari Formula diatas kita dapat implementasi menjadi :

$$
d=\sqrt{\left(\text { lat }_{1}-\text { lat }_{2}\right)+\left(\operatorname{long}_{1}-\operatorname{long}_{2}\right)^{2}}
$$

Dimana :

$\mathrm{d}=$ Jarak dengan satuan kilometer $(\mathrm{Km})$ 
Lat $_{1} \quad=$ Latitude titik awal

Lat $_{2} \quad=$ Latitude titik tujuan

Long $_{1} \quad=$ Longitude titik awal

Long $_{2}=$ Longitude titik tujuan

Dari hasil formula tersebut dikalikan dengan 111.319 $\mathrm{km}(1$ derajat bumi $=111.319 \mathrm{~km})$. Berikut pseudocode algoritma $\mathrm{A}^{*}$.

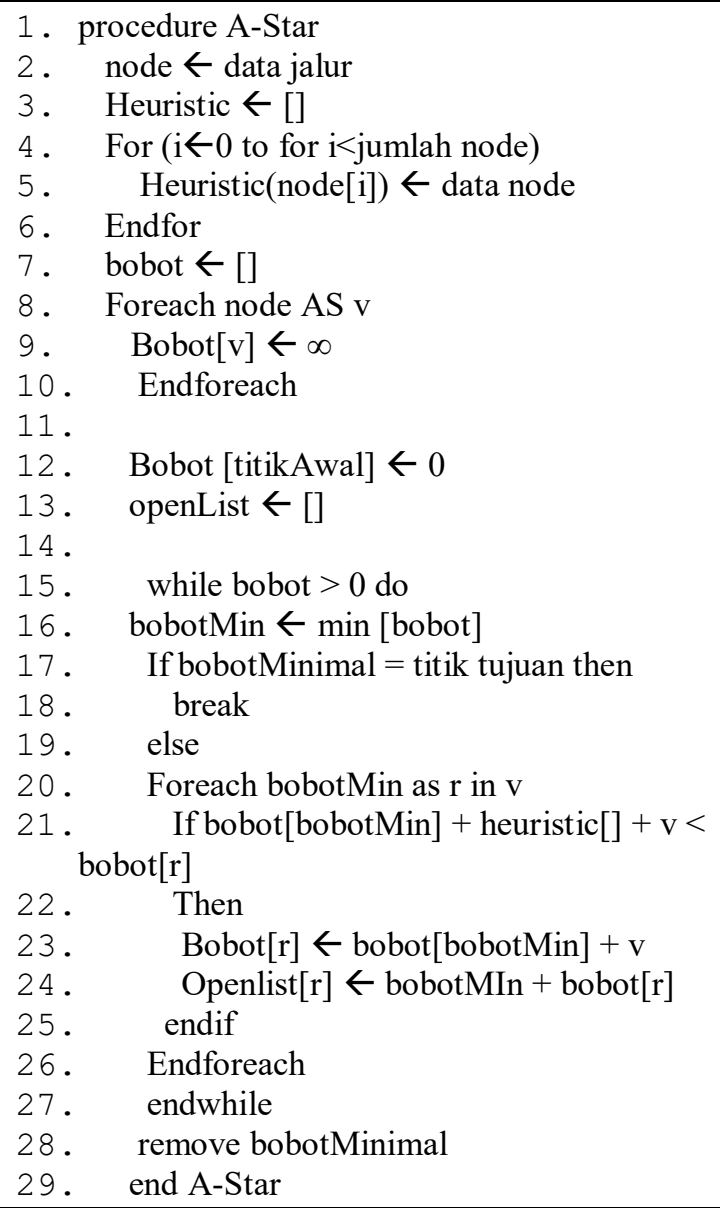

Gambar 4. Pseudocode Algoritma A*

\subsubsection{Algoritma Floyd Warshall}

Algoritma Floyd Warshall mempunyai jalur yang berbobot dan keluaran dari algoritma ini adalah dengan menghitung bobot minimum pada jalur yang saling berkaitan pada pasangan node, dan mengeksekusi pada semua pasangan node (Nawagusti, 2018). Floyd Warshall adalah teknik yang mengambil keuntungan dari subproblem yang tumpang tindih, substruktur optimal, dan memperdagangkan ruang untuk waktu guna meningkatkan kompleksitas runtime algoritma. Eksekusi algoritma tunggal akan menemukan jalur terpendek antara semua pasangan simpul (Cruz, Magwili, Mundo, Gregorio, Lamoca \& Villasenor, 2017). Berikut pseudocode algoritma Floyd Warshall.
1. procedure Floyd Warshall

2. graph $\leftarrow$ data jalur

3. $\operatorname{dist} \leftarrow[]$

4. pred $\leftarrow[]$

5. for $(i \leftarrow 0$ to $i<j u m a l a h$ data $)$

6. for $(j \leftarrow 0$ to $j<j u m a l a h$ data $)$

7. $\quad$ if $\mathrm{i}=\mathrm{j}$ then

8.

9.

10.

11.

12.

13.

14.

15. $\operatorname{pred}[\mathrm{i}, \mathrm{j}] \leftarrow[\mathrm{i}]$

16. endfor

17. for $(\mathrm{k} \leftarrow 0$ to $\mathrm{k}<\mathrm{jumalah}$ data $)$

18. for $(i \leftarrow 0$ to $i<j u m a l a h$ data $)$

19. for $(\mathrm{j} \leftarrow 0$ to $\mathrm{j}<\mathrm{jumalah}$ data $)$

20. If $\operatorname{dist}[\mathrm{i}, \mathrm{j}]>\operatorname{dist}[\mathrm{i}, \mathrm{k}]+\operatorname{dist}[\mathrm{k}, \mathrm{j}]$ then

21. $\operatorname{dist}[\mathrm{i}, \mathrm{j}]=\operatorname{dist}[\mathrm{i}, \mathrm{k}]+\operatorname{dist}[\mathrm{k}, \mathrm{j}]$

22. $\operatorname{pred}[\mathrm{i}, \mathrm{j}]=\operatorname{pred}[\mathrm{k}, \mathrm{j}]$

23. endfor

24. endfor

25. endfor

26. end Floyd Warshall

Gambar 5. Pseudocode Algoritma Floyd Warshall

\section{IMPLEMENTASI DAN HASIL}

\subsection{Pengujian Waktu Proses Algoritma}

Program dikembangkan menggunakan Bahasa pemograman PHP dan platform Leaflet.js sebagai tampilan maps. Kemudian program tersebut diujicoba dengan beberapa data tes. Adapun alat-alat pendukung dalam pengujian program sebagai berikut:

1. Hardware
a. Laptop Asus X441U
b. Prosessor Intel Core i3 $2.0 \mathrm{GHz}$

$$
\text { c. RAM } 4 G b
$$

2. Software
a. Sistem Operasi Windows 1064 Bit
b. Xampp 3.3.2.
c. Mozilla Firefox $71.064 \mathrm{bit}$

Terdapat 4 objek wisata dan 5 persimpangan. Setiap data akan dimasukan kedalam program kemudian diproses untuk mencari jalur terdekat.

Seperti terlihat pada gambar 6 terdapat 2 form input yang berfungsi untuk menentukan titik awal dan akhir dan 1 tombol untuk menjalankan program. Kemudian program dijalankan dengan cara menekan tombol cari.

Gambar 5 merupakan hasil komputasi algoritma Dijkstra yang telah diproses oleh program dengan menampilkan rute terdekat melalui maps, jarak tempuh, dan waktu proses. 


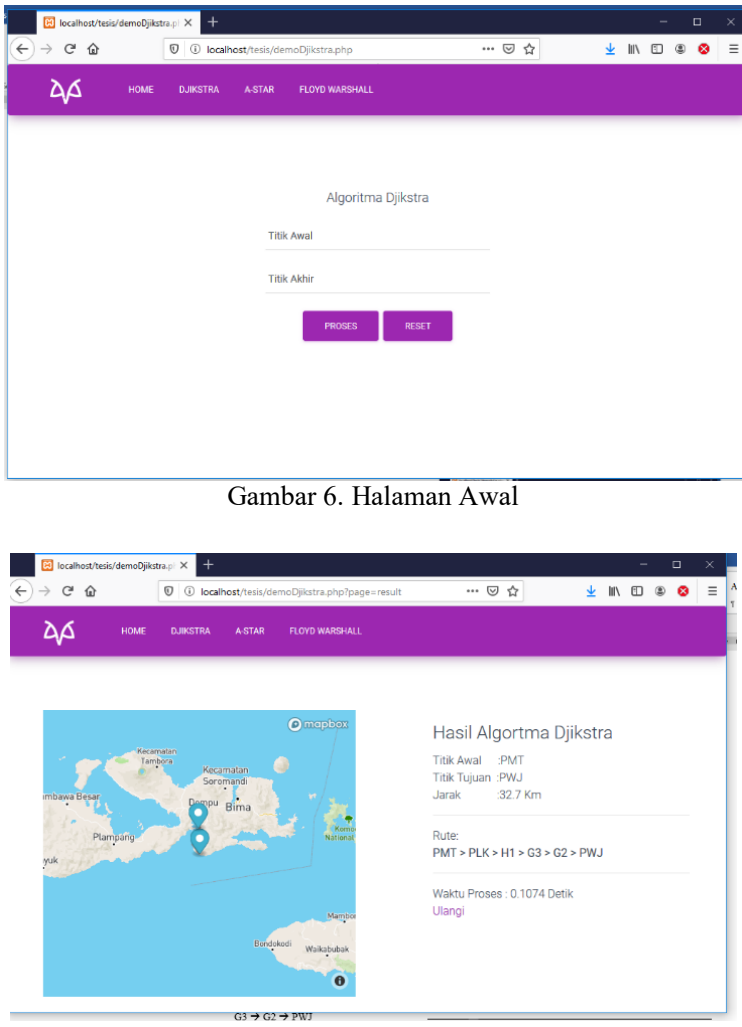

Gambar 7. Hasil algoritma Dijkstra

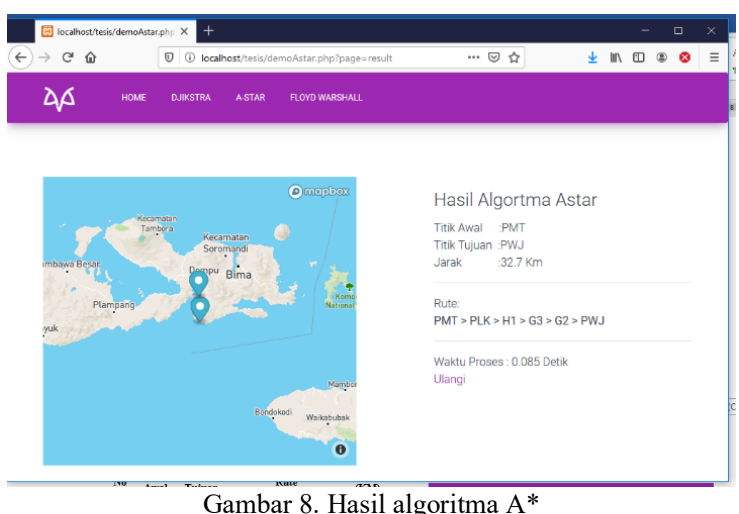

Gambar 8 merupakan hasil komputasi algoritma A* yang telah diproses oleh program dengan menampilkan rute terdekat melalui maps, jarak tempuh, dan waktu proses.

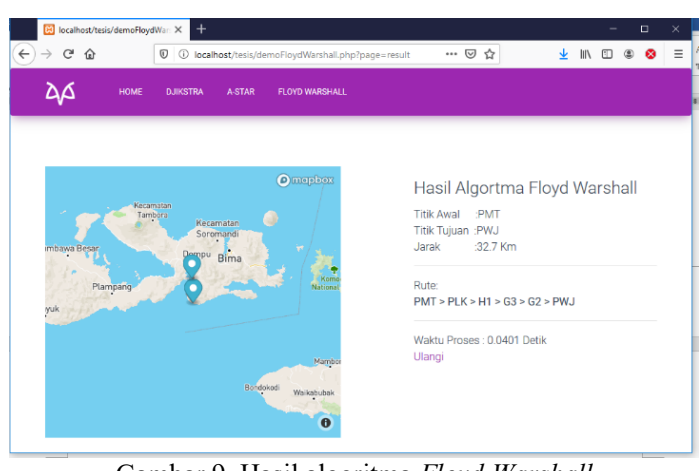

Gambar 9. Hasil algoritma Floyd Warshall
Gambar 9 merupakan hasil komputasi algoritma Floyd Warshall yang telah diproses oleh program dengan menampilkan rute terdekat melalui maps, jarak tempuh, dan waktu proses. Setelah program dijalankan mendapatkan hasil yang sama pada rute dan jarak akan tetapi rata-rata waktu proses program berbeda. Hasil jarak dan rute dari program dapat dilihat pada tabel 2,3 dan 4 .

\begin{tabular}{|c|c|c|c|c|}
\hline No & $\begin{array}{l}\text { Titik } \\
\text { Awal } \\
\end{array}$ & $\begin{array}{c}\text { Titik } \\
\text { Tujuan }\end{array}$ & Rute & $\begin{array}{l}\text { Jarak } \\
(\mathrm{KM})\end{array}$ \\
\hline \multirow[t]{3}{*}{1} & PWJ & PFJ & $\begin{array}{l}\mathrm{PWJ} \rightarrow \mathrm{G} 2 \rightarrow \mathrm{G} 3 \rightarrow \\
\mathrm{PFJ}\end{array}$ & 2,99 \\
\hline & & PLK & $\begin{array}{l}\mathrm{PWJ} \rightarrow \mathrm{G} 2 \rightarrow \mathrm{G} 3 \rightarrow \\
\mathrm{H} 1 \rightarrow \mathrm{PLK}\end{array}$ & 21 \\
\hline & & PMT & $\begin{array}{l}\mathrm{PWJ} \rightarrow \mathrm{G} 2 \rightarrow \mathrm{G} 3 \rightarrow \\
\mathrm{H} 1 \rightarrow \mathrm{PLK} \rightarrow \mathrm{PMT}\end{array}$ & 32,7 \\
\hline \multirow[t]{3}{*}{2} & PFJ & PWJ & $\begin{array}{l}\mathrm{PFJ} \rightarrow \mathrm{G} 3 \rightarrow \mathrm{G} 2 \rightarrow \\
\mathrm{PWJ}\end{array}$ & 2,99 \\
\hline & & PLK & $\begin{array}{l}\mathrm{PFJ} \rightarrow \mathrm{G} 3 \rightarrow \mathrm{H} 1 \rightarrow \\
\mathrm{PLK}\end{array}$ & 18,39 \\
\hline & & PMT & $\begin{array}{l}\mathrm{PFJ} \rightarrow \mathrm{G} 3 \rightarrow \mathrm{H} 1 \rightarrow \\
\mathrm{PLK} \rightarrow \mathrm{PMT}\end{array}$ & 30,09 \\
\hline \multirow[t]{3}{*}{3} & PLK & PWJ & $\begin{array}{l}\mathrm{PLK} \rightarrow \mathrm{H} 1 \rightarrow \mathrm{G} 3 \rightarrow \\
\mathrm{G} 2 \rightarrow \mathrm{PWJ}\end{array}$ & 21 \\
\hline & & PFJ & $\begin{array}{l}\mathrm{PLK} \rightarrow \mathrm{H} 1 \rightarrow \mathrm{G} 3 \rightarrow \\
\mathrm{PFJ}\end{array}$ & 18,39 \\
\hline & & PMT & PLK $\rightarrow$ PMT & 11,7 \\
\hline \multirow[t]{3}{*}{4} & PMT & PWJ & $\begin{array}{l}\mathrm{PMT} \rightarrow \mathrm{PLK} \rightarrow \mathrm{H} 1 \rightarrow \\
\mathrm{G} 3 \rightarrow \mathrm{G} 2 \rightarrow \mathrm{PWJ}\end{array}$ & 32,7 \\
\hline & & PFJ & $\begin{array}{l}\mathrm{PLK} \rightarrow \mathrm{H} 1 \rightarrow \mathrm{G} 3 \rightarrow \\
\mathrm{PFJ}\end{array}$ & 30,09 \\
\hline & & PLK & PMT $\rightarrow$ PLK & 11,7 \\
\hline
\end{tabular}

\begin{tabular}{|c|c|c|c|c|}
\hline No & $\begin{array}{l}\text { Titik } \\
\text { Awal }\end{array}$ & $\begin{array}{c}\text { Titik } \\
\text { Tujuan }\end{array}$ & Rute & $\begin{array}{l}\text { Jarak } \\
(\mathrm{KM})\end{array}$ \\
\hline \multirow[t]{3}{*}{1} & PWJ & PFJ & $\begin{array}{l}\mathrm{PWJ} \rightarrow \mathrm{G} 2 \rightarrow \mathrm{G} 3 \rightarrow \\
\mathrm{PFJ}\end{array}$ & 2,99 \\
\hline & & PLK & $\begin{array}{l}\mathrm{PWJ} \rightarrow \mathrm{G} 2 \rightarrow \mathrm{G} 3 \rightarrow \\
\mathrm{H} 1 \rightarrow \mathrm{PLK}\end{array}$ & 21 \\
\hline & & PMT & $\begin{array}{l}\mathrm{PWJ} \rightarrow \mathrm{G} 2 \rightarrow \mathrm{G} 3 \rightarrow \\
\mathrm{H} 1 \rightarrow \mathrm{PLK} \rightarrow \mathrm{PMT}\end{array}$ & 32,7 \\
\hline \multirow[t]{3}{*}{2} & PFJ & PWJ & $\begin{array}{l}\mathrm{PFJ} \rightarrow \mathrm{G} 3 \rightarrow \mathrm{G} 2 \rightarrow \\
\mathrm{PWJ}\end{array}$ & 2,99 \\
\hline & & PLK & $\begin{array}{l}\mathrm{PFJ} \rightarrow \mathrm{G} 3 \rightarrow \mathrm{H} 1 \rightarrow \\
\mathrm{PLK}\end{array}$ & 18,39 \\
\hline & & PMT & $\begin{array}{l}\mathrm{PFJ} \rightarrow \mathrm{G} 3 \rightarrow \mathrm{H} 1 \rightarrow \\
\mathrm{PLK} \rightarrow \mathrm{PMT}\end{array}$ & 30,09 \\
\hline \multirow[t]{3}{*}{3} & PLK & PWJ & $\begin{array}{l}\mathrm{PLK} \rightarrow \mathrm{H} 1 \rightarrow \mathrm{G} 3 \rightarrow \\
\mathrm{G} 2 \rightarrow \mathrm{PWJ}\end{array}$ & 21 \\
\hline & & PFJ & $\begin{array}{l}\mathrm{PLK} \rightarrow \mathrm{H} 1 \rightarrow \mathrm{G} 3 \rightarrow \\
\mathrm{PFJ}\end{array}$ & 18,39 \\
\hline & & PMT & PLK $\rightarrow$ PMT & 11,7 \\
\hline \multirow[t]{3}{*}{4} & PMT & PWJ & $\begin{array}{l}\mathrm{PMT} \rightarrow \mathrm{PLK} \rightarrow \mathrm{H} 1 \rightarrow \\
\mathrm{G} 3 \rightarrow \mathrm{G} 2 \rightarrow \mathrm{PWJ}\end{array}$ & 32,7 \\
\hline & & PFJ & $\begin{array}{l}\mathrm{PLK} \rightarrow \mathrm{H} 1 \rightarrow \mathrm{G} 3 \rightarrow \\
\mathrm{PFJ}\end{array}$ & 30,09 \\
\hline & & PLK & PMT $\rightarrow$ PLK & 11,7 \\
\hline
\end{tabular}

Tabel 4 Hasil uji program algoritma Floyd Warshall

\begin{tabular}{lllll}
\hline No & $\begin{array}{c}\text { Titik } \\
\text { Awal }\end{array}$ & $\begin{array}{c}\text { Titik } \\
\text { Tujuan }\end{array}$ & \multicolumn{1}{c}{ Rute } & $\begin{array}{c}\text { Jarak } \\
\text { (KM) }\end{array}$ \\
\hline 1 & PWJ & PFJ & PWJ $\rightarrow$ G2 $\rightarrow$ G3 $\rightarrow$ & 2,99 \\
& & & PFJ & \\
& & PLK & PWJ $\rightarrow$ G2 $\rightarrow \mathrm{G} 3 \rightarrow$ & 21 \\
& & H1 $\rightarrow$ PLK & \\
& & PMT & $\begin{array}{l}\text { PWJ } \rightarrow \text { G2 } \rightarrow \text { G3 } \rightarrow \\
\text { H1 } \rightarrow \text { PLK } \rightarrow \text { PMT }\end{array}$ & \\
& & &
\end{tabular}




\begin{tabular}{|c|c|c|c|c|}
\hline No & $\begin{array}{l}\text { Titik } \\
\text { Awal }\end{array}$ & $\begin{array}{c}\text { Titik } \\
\text { Tujuan }\end{array}$ & Rute & $\begin{array}{l}\text { Jarak } \\
\text { (KM) }\end{array}$ \\
\hline \multirow[t]{3}{*}{2} & PFJ & PWJ & $\begin{array}{l}\mathrm{PFJ} \rightarrow \mathrm{G} 3 \rightarrow \mathrm{G} 2 \rightarrow \\
\mathrm{PWJ}\end{array}$ & 2,99 \\
\hline & & PLK & $\begin{array}{l}\mathrm{PFJ} \rightarrow \mathrm{G} 3 \rightarrow \mathrm{H} 1 \rightarrow \\
\mathrm{PLK}\end{array}$ & 18,39 \\
\hline & & PMT & $\begin{array}{l}\mathrm{PFJ} \rightarrow \mathrm{G} 3 \rightarrow \mathrm{H} 1 \rightarrow \\
\mathrm{PLK} \rightarrow \mathrm{PMT}\end{array}$ & 30,09 \\
\hline \multirow[t]{3}{*}{3} & PLK & PWJ & $\begin{array}{l}\mathrm{PLK} \rightarrow \mathrm{H} 1 \rightarrow \mathrm{G} 3 \rightarrow \\
\mathrm{G} 2 \rightarrow \mathrm{PWJ}\end{array}$ & 21 \\
\hline & & PFJ & $\begin{array}{l}\mathrm{PLK} \rightarrow \mathrm{H} 1 \rightarrow \mathrm{G} 3 \rightarrow \\
\mathrm{PFJ}\end{array}$ & 18,39 \\
\hline & & PMT & $\mathrm{PLK} \rightarrow \mathrm{PMT}$ & 11,7 \\
\hline \multirow[t]{3}{*}{4} & PMT & PWJ & $\begin{array}{l}\mathrm{PMT} \rightarrow \mathrm{PLK} \rightarrow \mathrm{H} 1 \rightarrow \\
\mathrm{G} 3 \rightarrow \mathrm{G} 2 \rightarrow \mathrm{PWJ}\end{array}$ & 32,7 \\
\hline & & PFJ & $\begin{array}{l}\mathrm{PLK} \rightarrow \mathrm{H} 1 \rightarrow \mathrm{G} 3 \rightarrow \\
\mathrm{PFJ}\end{array}$ & 30,09 \\
\hline & & PLK & PMT $\rightarrow$ PLK & 11,7 \\
\hline
\end{tabular}

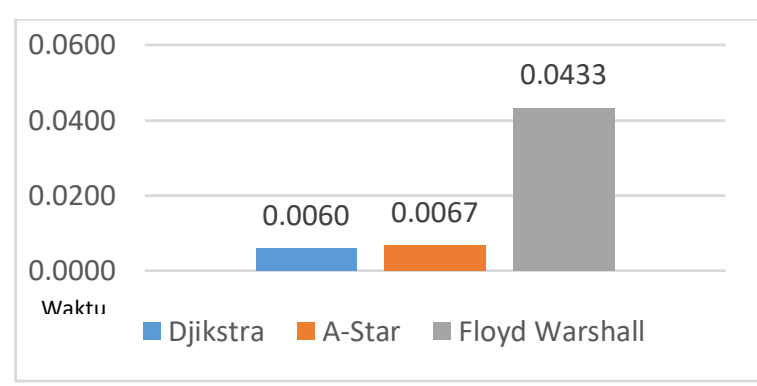

Gambar 9. Rata-rata waktu proses ketiga algoritma

Gambar 9 merupakan hasul rata-rata waktu proses dari ketiga algoritma yang didapat dari proses eksekusi program.

\subsection{Komplesitas Waktu (Big-O)}

Dari analisis pseudocede ketiga algoritma dapat diketahui bahwa kompleksitas waktu algoritma Dijkstra adalah $f(n)=O\left(n+n^{2}\right)$, algoritma $\mathrm{A}^{*}$ adalah $f(n)=O\left(2 n+n^{2}\right)$ dan algoritma Floyd Warshall adalah $f(n)=O\left(n^{2}+n^{3}\right)$. Ketiga kompleksitas waktu tersebut dapat dilihat dalam bentuk grafik seperti pada gambar 10

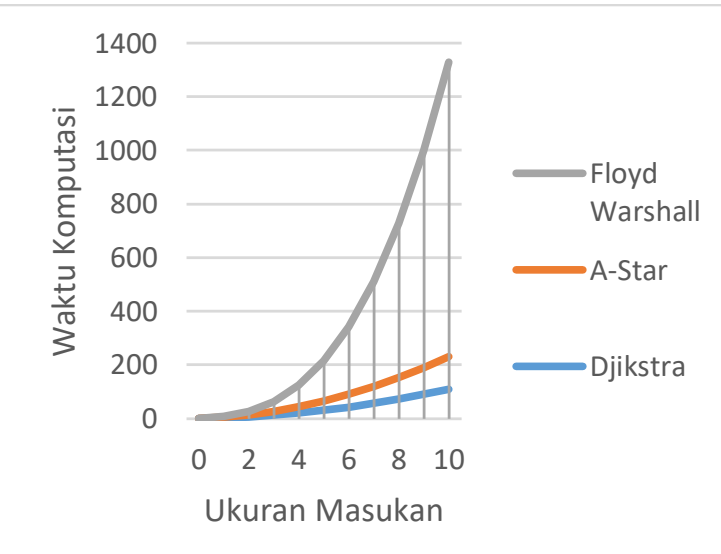

Gambar 10. Komplesitas Waktu ketiga algoritma

Dari gambar 10 dilihat bahwa penggunaan algoritma Dijkstra memiliki nilai komputasi waktu terrendah dari pada algoritma $\mathrm{A}^{*}$ dan Floyd Warshall

\section{KESIMPULAN}

Dari pengujian program didapatkan jarak dan rute yang sama serta rata-rata waktu proses program yang berbeda. Waktu proses algoritma Dijkstra sebesar 0,0060 detik, algoritma $A^{*}$ sebesar 0,0067 dan algoritma Floyd Warshall sebesar 0,0433 detik. Berdasarkan hasil tersebut bahwa algoritma Dijkstra lebih unggul dalam proses pencarian rute.

\section{DAFTAR PUSTAKA}

AGUSTA, D. \& FERDINAND, F. N. (2017) 'DJIKSTRA Algorithm Based Approach to Shortest Path Model in Public Bus Transportation', International Journal of Computer Science Engineering and Information Technology Research, 7(6), pp. 1-8. doi: $10.24247 / \mathrm{ijcseitrdec} 20171$.

ARDYAN, S., MULYONO \& SUYITNO, A. (2017) 'Implementasi Algoritma Dijkstra Dalam Pencarian Rute Terpendek Tempat Wisata Di Kabupaten', UNNES Journal of Mathematics, 6(2), pp. 108-116.

ARIYANTI, R., KHAIRIL AND KANEDI, I. (2015) 'Pemanfaatan Google Maps Api Pada Sistem Informasi Geografis Direktori Perguruan Tinggi Di Kota Bengkulu', Media Infotama, 11(2), pp. 119-129.

CAHYADI, M. A., BAMBANG, M. A. P., WIDHIARSO, W., YOHANNES. (2016) 'Perbandingan Algoritma A*, Dijkstra dan Floyd Warshall Untuk Menentukan Jalur Terpendek Pada Permainan "Bacteria Defense", Teknik Tnformatika.

CRUZ, J. C. D., MAGWILI, G. V., MUNDO, J. P. E., GREGORIO, G. P. B., LAMOCA, M. L. L., VILLASENOR, J. A (2017) 'Itemsmapping and route optimization in a grocery store using Dijkstra's, Bellman-Ford and Floyd-Warshall Algorithms', IEEE Region 10 Annual International Conference, Proceedings/TENCON, pp. 243-246. doi: 10.1109/TENCON.2016.7847998.

MANURUNG, S. (2018) Mengenal Leaflet Js, Alternatif Membangun Peta Interaktif Berbasis Web Tanpa Google Maps Api. Available at: https://www.sgtgeomedia.com/detailpost/m engenal-leaflet-js-alternatif-membangunpeta-interaktif-berbasis-web-tanpa-googlemaps-api.

NAWAGUSTI, V. A. (2018) 'Penerapan Algoritma Floyd Warshall Dalam Aplikasi Penentuan Rute Terpendek Mencari Lokasi BTS (Base Tower Station) Pada PT.GCI Palembang', Jurnal Nasional Teknologi dan Sistem Informasi, 4(2), pp. 81-88. doi: 10.25077/teknosi.v4i2.2018.81-88.

NINGRUM, F. W. \& ANDRASTO, T. (2016) 'Penerapan Algoritma Floyd-Warshall dalam Menentukan Rute Terpendek pada Pemodelan Jaringan Pariwisata di Kota 
Semarang', Jurnal Teknik Elektro, 8(1), pp. 21-24.

PUGAS, D. OK., SOMANTRI, M. \& SATOTO, K. I. (2014) 'Pencarian Rute Terpendek Menggunakan Algoritma Dijkstra dan Astar (A*) pada SIG Berbasis Web untuk Pemetaan Pariwisata Kota Sawahlunto', Transmisi.

SAZAKI, Y., SATRIA, H., PRIMANITA, A., SYAHROYNI, M (2018) 'ANALISA PERBANDINGAN ALGORITMA A * DAN DYNAMIC PATHFINDING ALGORITHM DENGAN DYNAMIC PATHFINDING ALGORITHM UNTUK NPC', 5(1), pp. 95-103. doi: 10.25126/jtiik.

SETIAWAN, A., ANDRIYANTO, F., PUTRO, L. S., PRADANA, N. T. P., PERMANA, U (2018) 'Menghitung Rute Terpendek Menggunakan Algoritma A* Dengan Fungsi Euclidean Distance', SENTIKA 2018, 2018(Sentika), pp. 23-24.

SHABINA BANU MANSURI, S. K. (2018) 'Comparative Analysis of Path Finding Algorithms', IOSR Journal of Computer Engineering, 20(5), pp. 38-45.

SIDIK, B. (2017) Pemograman Web Dengan PHP 7. Bandung: Informatika.

SUNARDI, S., YUDHANA, A. \& KADIM, A. A. (2019) 'Implementasi Algoritma Dijkstra dan Algoritma Semut Untuk Analisis Rute Transjogja Berbasis Android', It Journal Research and Development, 01, pp. 32-38. doi: 10.25299/itjrd.2019.vol4(1).2483.

SUYITNO, P. P. W. (2016) 'Pencarian Jalur Terpendek dari Rumah Menuju Candi Jiwa Batujaya Menggunakan Algoritma A-Star', II STMIK Nusa Mandiri. ISBN: 978-60272850-1-9, pp. 169-174.

UMAR, R. \& HARI PRABOWO, P. (2016) 'Pencarian Dan Pemesanan Travel Berbasis Mobile dengan Google Maps API', Annual Research Seminar 2016, 2(ISBN : 979-587626-0), pp. 369-372.

WAHYUNINGSIH, D. \& SYAHREZA, E. (2018) 'Shortest Path Search Futsal Field Location With Dijkstra Algorithm', IJCCS (Indonesian Journal of Computing and Cybernetics Systems), 12(2), p. 161. doi: 10.22146/ijccs.34513.

WANG, C., WANG, L., QIN, J., WU, Z., PUAN, L., CAO, Z. L. M, OU, X (2015) 'Path planning of automated guided vehicles based on improved A-Star algorithm', 2015 IEEE International Conference on Information and Automation, ICIA 2015 - In conjunction with 2015 IEEE International Conference on Automation and Logistics, (August), pp. 2071-2076. doi:10.1109/ICInfA.2015.7279630. 
Halaman ini sengaja dikosongkan 